\title{
Bioactivity of essential oils from cultivated winter savory, sage and hyssop
}

\author{
Milica Aćımović ${ }^{1, *}$, Marina TodosiJević ${ }^{2}$, Ana Varga ${ }^{3}$, Biljana KIPRovski ${ }^{1}$, Vele Tešević ${ }^{2}$, \\ IVANA ČABARKAPA ${ }^{3}$, AND VLADIMIR SIKORA ${ }^{1}$
}

${ }^{1}$ Institute of Field and Vegetable Crops Novi Sad, Maksima Gorkog 30, 21000 Novi Sad, Serbia

${ }^{2}$ University of Belgrade, Faculty of Chemistry, Studentski trg 12-16, 11000 Belgrade, Serbia

${ }^{3}$ University of Novi Sad, Institute of Food Technology Novi Sad, Bulevar cara Lazara 1, 21000 Novi Sad, Serbia

*Corresponding author: milica.acimovic@ifvcns.ns.ac.rs

Received: April 23, 2019

Accepted: August 6, 2019

Published on-line: October 25, 2019

Published: December 25, 2019

\begin{abstract}
Species of the Lamiaceae family have enjoyed a rich tradition of use for flavoring, food preservation, and medicinal purposes, due to their curative and preventive properties. Cultivated winter savory (Satureja montana L.), sage (Salvia officinalis L.) and hyssop (Hyssopus officinalis L.) are produced for seed, herb, and essential oil. Dominant compounds in S. montana essential oil were carvacrol (43.2\%) and thymol $(28.4 \%)$, while cis-thujone $(27.1 \%)$ and camphor $(19.3 \%)$, followed by trans-thujone and 1,8-cineole were the major compounds in S. officinalis essential oil. As for H. officinalis essential oil, cis- and trans-pinocamphone $(41.1 \%$ and $20.5 \%$, respectively) were the most abundant compounds, followed by $\beta$-pinene. S. montana essential oil exhibit the highest antimicrobial properties, as well as antioxidant capacity, compared to other tested essential oils. Furthermore, $H$. officinalis essential oils showed higher antioxidant activity than that of $S$. officinalis. The aim of this investigation was to determine the composition and bioactivity of essential oils of mentioned varieties. Presented results show that $S$. montana essential oil could be proposed as a valuable source of natural preservatives.
\end{abstract}

Key words: Satureja montana; Salvia officinalis; Hyssopus officinalis; antibacterial; antioxidant

http://dx.doi.org/10.5937/leksir1939011A

\section{INTRODUCTION}

Species of the family Lamiaceae have a long and a rich tradition of use for flavoring, food preservation, and medicinal purposes, due to their curative and preventive properties (Carović-Stanko et al., 2016). The majority of aromatic species belong to the Lamiaceae family, which is one of the largest families among the dicotyledons (Venkateshappa and Sreenath, 2013).

Winter savory (Satureja montana) is well known as a medicinal herb, mainly as a muscle pain reliever, tonic, and carminative agent in order to treat stomach and intestinal disorders such as cramps, nausea, indigestion, and diarrhea (Tepe and Cilkiz, 2016). It has a strong and spicy taste, and therefore it is used as a flavoring agent in salads, soups, sauces, stews, and lentil dishes (Wesołowska et al., 2014).

Sage (Salvia officinalis) has been used for culinary purposes as spice and preservative throughout history, but today it is commonly used to flavor meat, seafood, and cheese (Mapes and $\mathrm{Xu}, 2014)$. In traditional medicine, sage has been used to treat mild dyspepsia (such as heartburn and bloating), excessive sweating, age-related cognitive disorders, and inflammations in the throat and skin (Ghorbani and Esmaeilizadeh, 2017).
Sage leaf (Salviae officinalis folium) has been listed in European Pharmacopoeia and many others (Ph. Eur. 7.0., 2010).

Despite its slightly bitter taste and minty flavor, hyssop (Hyssopus officinalis) is commonly used for centuries to produce flavors and fragrances in food, mainly sauces, and seasonings, and in bitters and liqueurs (Dehghanzadeh et al., 2012). Apart from this, it is used in folk medicine as a carminative, tonic, antiseptic, expectorant and cough reliever (Fathiazad et al., 2011).

Because of bioactive components in their essential oils, characterized by specific taste and fragrance, mentioned plants are popular today in the concept of functional food. In recent years, many research studies have been conducted to find new biological effects of plants including antioxidant, antimicrobial, anticancer, hypoglycemic and hypolipidemic effects. Sage represents a most common medicinal plant that is cultivated and collected from natural habitats. However, $S$. montana and especially, $H$. officinalis, are rarely cultivated and their natural habitats are constricted to sparse population area. Due to the extensive harvest of these plants in their natural habitats, comparison of quality and biological activity of essential oil between cultivated and wild plants is important to 
all parties which use these species.

Bearing in mind numerous properties of savory, sage and hyssop, the aim of this paper was to determine chemical composition and content, as well as biological activity of essential oils of these plants grown in our collection and to compare these findings to available literature data.

\section{MATERIALS AND METHODS}

\subsection{Plant material}

As a part of medicinal plants collection of the Institute of Field and Vegetable Crops in Novi Sad, located in Bački Petrovac, at the Department for Alternative Crops and Organic Production, winter savory (S. montana L., variety "Domaći"), sage (S. officinalis L., variety "Primorska") and hyssop (H. officinalis L., variety "Domaći ljubičasti") are produced for essential oil extraction. Above-ground parts of selected plants were collected in July 2017. Voucher specimens were confirmed and deposited at the Herbarium of the Department of Biology and Ecology (BUNS Herbarium), Faculty of Sciences, University of Novi Sad. Voucher specimens were referenced as 2-1561 (S. montana), 2-1548 (S. officinalis) and 2-1567 (H. officinalis).

\subsection{Essential oil extraction}

Dried samples of winter savory, sage and hyssop were subjected to hydro-distillation using an all-glass Clevenger-type apparatus to extract essential oils according to the method outlined by the European Pharmacopoeia (Ph. Eur. 7.0., 2010). In order to extract the essential oils, $100 \mathrm{~g}$ of the plant material was placed in $1 \mathrm{~L}$ conical flask and connected to the Clevenger apparatus. Distilled water was added to the flask $(500 \mathrm{~mL})$ and heated to the boiling point. The steam in combination with the essential oils was distilled into a graduated cylinder for $4 \mathrm{~h}$ and then separated from the aqueous layer. Essential oils were kept refrigerated until further analysis.

\section{3. $\mathrm{GC}$ and $\mathrm{GC}-\mathrm{MS}$ analysis}

The gas chromatographic-mass spectrometric analysis was performed using an Agilent 6890 gas chromatograph coupled with an Agilent 5973 Network transmission quadrupole mass spectrometer (Agilent, Santa Clara, USA), in positive ion-electron impact (EI) mode. The separation of individual compounds was achieved using non-polar HP-5 fused silica capillary column with $30 \mathrm{~m} \times 0.25 \mathrm{~mm}$ i.d., $0.25 \mu \mathrm{m}$ film thickness. The GC oven temperature was programmed from $60^{\circ} \mathrm{C}$ to $285^{\circ} \mathrm{C}$ at a rate of $3{ }^{\circ} \mathrm{C} / \mathrm{min}$. Helium was used as carrier gas; inlet pressure was $20.3 \mathrm{kPa}$; linear velocity was $1 \mathrm{~mL} / \mathrm{min}$ at $210{ }^{\circ} \mathrm{C}$. Injector temperature: $250^{\circ} \mathrm{C}$; injection mode: splitless. MS scan conditions: MS source temperature, $230^{\circ} \mathrm{C}$; MS Quad temperature, $150{ }^{\circ} \mathrm{C}$; energy, $70 \mathrm{eV}$; mass scan range, $40-550$ amu. The identification of components was carried out on the basis of retention indices followed by comparison with reference spectra (Wiley and NIST databases) and literature data.

\subsection{Antibacterial activity}

The antimicrobial activity was evaluated using control strains obtained from the American Type Culture Collection. Four Gram-positive bacteria: Bacillus cereus (ATCC 11778), Enterococcus faecalis (ATCC 29212), Staphylococcus aureus (ATCC 25923) and Staphylococcus epidermidis (ATCC 12228), and four Gram-negative bacteria: Escherichia coli (ATCC 8739), Pseudomonas aeruginosa (ATCC 27853), Salmonella enteritidis (ATCC 13076), and Proteus hauseri (ATCC 13315). The activity of essential oils was tested by a modified broth microdilution method according to the National Committee for Clinical Laboratory Standards (CLSI, 2012). A serial doubling dilution of the tested essential oils was prepared in a 96-well microtiter plates over
Table 1. The essential oil composition of winter savory ( $S$. montana).

\begin{tabular}{|c|c|c|c|}
\hline \# & Compound name ${ }^{a}$ & $\mathrm{RI}^{\mathrm{a}}$ & $\% \mathrm{~m} / \mathrm{m}$ \\
\hline 1 & $\alpha$-thujene & 924 & 0.6 \\
\hline 2 & $\alpha$-pinene & 932 & 0.6 \\
\hline 3 & n.i. & 942 & $\operatorname{tr}$ \\
\hline 4 & camphene & 946 & 0.3 \\
\hline 5 & 1-octen-3-ol & 975 & 0.4 \\
\hline 6 & $\beta$-pinene & 975 & 0.2 \\
\hline 7 & myrcene & 989 & 1.1 \\
\hline 8 & $\alpha$-phellandrene & 1004 & 0.2 \\
\hline 9 & $\delta$-3-carene & 1010 & 0.1 \\
\hline 10 & $\alpha$-terpinene & 1015 & 1.7 \\
\hline 11 & p-cymene & 1024 & 8.9 \\
\hline 12 & limonene & 1027 & 0.5 \\
\hline 13 & 1,8-cineole & 1029 & 0.3 \\
\hline 14 & cis- $\beta$-ocimene & 1036 & $\operatorname{tr}$ \\
\hline 15 & $\gamma$-terpinene & 1057 & 7.5 \\
\hline 16 & cis-sabinene hydrate & 1065 & 0.5 \\
\hline 17 & terpinolene & 1088 & $\operatorname{tr}$ \\
\hline 18 & n.i. & 1099 & 0.1 \\
\hline 19 & linalool & 1100 & 0.5 \\
\hline 20 & cis-thujone & 1106 & $\operatorname{tr}$ \\
\hline 21 & camphor & 1143 & $\operatorname{tr}$ \\
\hline 22 & trans-pinocamphone & 1159 & $\operatorname{tr}$ \\
\hline 23 & borneol & 1163 & 0.4 \\
\hline 24 & cis-pinocamphone & 1172 & 0.1 \\
\hline 25 & terpinen-4-ol & 1175 & 0.5 \\
\hline 26 & $\alpha$-terpineol & 1189 & 0.1 \\
\hline 27 & carvacrol, methyl ether & 1242 & 0.4 \\
\hline 28 & n.i. & 1282 & $\operatorname{tr}$ \\
\hline 29 & thymol & 1292 & 28.4 \\
\hline 30 & carvacrol & 1301 & 43.2 \\
\hline 31 & $\alpha$-copaene & 1375 & $\operatorname{tr}$ \\
\hline 32 & $\beta$-bourbonene & 1384 & $\operatorname{tr}$ \\
\hline 33 & trans-caryophyllene & 1419 & 1.4 \\
\hline 34 & $\beta$-copaene & 1429 & $\operatorname{tr}$ \\
\hline 35 & aromadendrene & 1439 & $\operatorname{tr}$ \\
\hline 36 & $\alpha$-humulene & 1453 & $\operatorname{tr}$ \\
\hline 37 & $\gamma$-muurolene & 1477 & 0.1 \\
\hline 38 & viridiflorene & 1496 & 0.1 \\
\hline 39 & n.i. & 1501 & $\operatorname{tr}$ \\
\hline 40 & $\beta$-bisabolene & 1510 & 0.7 \\
\hline 41 & $\gamma$-cadinene & 1515 & 0.1 \\
\hline 42 & $\delta$-cadinene & 1524 & 0.2 \\
\hline 43 & n.i. & 1578 & $\operatorname{tr}$ \\
\hline 44 & caryophyllene oxide & 1583 & 0.3 \\
\hline 45 & n.i. & 1904 & $\operatorname{tr}$ \\
\hline 46 & n.i. & 1931 & $\operatorname{tr}$ \\
\hline 47 & n.i. & 2147 & $\operatorname{tr}$ \\
\hline \multirow[t]{7}{*}{48} & n.i. & 2164 & $\operatorname{tr}$ \\
\hline & Monoterpene hydrocarbons & & 21.1 \\
\hline & Oxigenatedmonoterpenes & & 75.0 \\
\hline & Sesquiterpene hydrocarbons & & 2.6 \\
\hline & Oxigenatedsesquiterpenes & & 0.3 \\
\hline & Other & & 0.4 \\
\hline & Total identified & & 99.5 \\
\hline
\end{tabular}

${ }^{a}$ n.i. stands for not identified compounds; $\operatorname{tr}$ - traces.

${ }^{\mathrm{b}} \mathrm{RI}$, retention indices as determined on HP- 5 column using homologous series of $\mathrm{C}_{8}-\mathrm{C}_{30}$ alkanes. 
Table 2. The essential oil composition of sage S. officinalis.

\begin{tabular}{|c|c|c|c|}
\hline$\#$ & Compound name ${ }^{a}$ & $\mathrm{RI}^{\mathrm{a}}$ & $\% \mathrm{~m} / \mathrm{m}$ \\
\hline 1 & cis-salvene & 846 & 0.4 \\
\hline 2 & trans-salvene & 856 & $\operatorname{tr}$ \\
\hline 3 & n.i. & 918 & $\operatorname{tr}$ \\
\hline 4 & tricyclene & 922 & 0.1 \\
\hline 5 & $\alpha$-thujene & 925 & 0.1 \\
\hline 6 & $\alpha$-pinene & 932 & 3 \\
\hline 7 & camphene & 947 & 4.6 \\
\hline 8 & sabinene & 972 & 0.1 \\
\hline 9 & $\beta$-pinene & 976 & 1.6 \\
\hline 10 & myrcene & 989 & 0.8 \\
\hline 11 & $\alpha$-phellandrene & 1005 & $\operatorname{tr}$ \\
\hline 12 & $\alpha$-terpinene & 1016 & 0.2 \\
\hline 13 & $p$-cymene & 1024 & 0.4 \\
\hline 14 & limonene & 1028 & 4.4 \\
\hline 15 & 1,8-cineole & 1031 & 11.5 \\
\hline 16 & $\gamma$-terpinene & 1057 & 0.4 \\
\hline 17 & cis-sabinene hydrate & 1066 & 0.1 \\
\hline 18 & terpinolene & 1088 & 0.2 \\
\hline 19 & trans-sabinene hydrate & 1103 & 0.1 \\
\hline 20 & linalool & 1108 & 0.3 \\
\hline 21 & cis-thujone & 1110 & 27.1 \\
\hline 22 & trans-thujone & 1119 & 12.3 \\
\hline 23 & $\alpha$-campholenal & 1126 & $\operatorname{tr}$ \\
\hline 24 & iso-3-thujanol & 1138 & 0.1 \\
\hline 25 & n.i. & 1143 & $\operatorname{tr}$ \\
\hline 26 & camphor & 1147 & 19.3 \\
\hline 27 & trans-pinocamphone & 1159 & $\operatorname{tr}$ \\
\hline 28 & borneol & 1164 & 0.9 \\
\hline 29 & terpinen-4-ol & 1175 & 0.4 \\
\hline 30 & $\alpha$-terpineol & 1188 & $\operatorname{tr}$ \\
\hline 31 & n.i. & 1196 & $\operatorname{tr}$ \\
\hline 32 & bornyl acetate & 1284 & 0.5 \\
\hline 33 & trans-sabinylacetate & 1291 & 0.1 \\
\hline 34 & trans-carvyl acetate & 1337 & $\operatorname{tr}$ \\
\hline 35 & trans-caryophyllene & 1419 & 1.7 \\
\hline 36 & n.i. & 1438 & $\operatorname{tr}$ \\
\hline 37 & $\alpha$-humulene & 1454 & 2.4 \\
\hline 38 & 9-epi-trans-caryophyllene & 1461 & $\operatorname{tr}$ \\
\hline 39 & viridiflorene & 1496 & $\operatorname{tr}$ \\
\hline 40 & caryophyllene oxide & 1582 & 0.3 \\
\hline 41 & viridiflorol & 1591 & 3.4 \\
\hline 42 & n.i. & 1598 & 0.1 \\
\hline 43 & humulene epoxide II & 1609 & 0.7 \\
\hline 44 & n.i. & 1630 & $\operatorname{tr}$ \\
\hline 45 & n.i. & 1673 & 0.1 \\
\hline 46 & n.i. & 1781 & $\operatorname{tr}$ \\
\hline 47 & n.i. & 1806 & $\operatorname{tr}$ \\
\hline 48 & isopimara-9(11),15-diene & 1913 & $\operatorname{tr}$ \\
\hline 49 & n.i. & 1932 & $\operatorname{tr}$ \\
\hline 50 & n.i. & 2001 & $\operatorname{tr}$ \\
\hline 51 & manool & 2061 & 1.9 \\
\hline \multirow[t]{9}{*}{52} & n.i. & 2094 & $\operatorname{tr}$ \\
\hline & Norterpenes & & 0.4 \\
\hline & Monoterpene hydrocarbons & & 15.9 \\
\hline & Oxigenated monoterpenes & & 72.7 \\
\hline & Sesquiterpene hydrocarbons & & 7.5 \\
\hline & Oxigenated sesquiterpenes & & 1 \\
\hline & Diterpene hydrocarbons & & $\operatorname{tr}$ \\
\hline & Oxigenated diterpenes & & 1.9 \\
\hline & Total identified & & 99.6 \\
\hline
\end{tabular}

a n.i. stands for not identified compounds; $\mathrm{tr}$ - traces.

${ }^{\mathrm{b}} \mathrm{RI}$, retention indices as determined on HP-5 column using homologous series of $\mathrm{C}_{8}-\mathrm{C}_{30}$ alkanes. the range of $454.4-0.22 \mu \mathrm{L} / \mathrm{mL}$ in inoculated Mueller-Hinton broth (MHB, HiMedia). The mixture was discharged from the last well in a row $(100 \mu \mathrm{L})$. The test was performed in a total volume of $110 \mu \mathrm{L} / \mathrm{mL}$ with a final microbial concentration of $106 \mathrm{CFU} / \mathrm{mL}$ per well. The plate was incubated for $24 \mathrm{~h}$ at $37^{\circ} \mathrm{C}$. The same tests were performed simultaneously for growth control (MHB + test organism), sterility control (MHB + test oil), and positive control (MHB + gentamicin+ test organism). Gentamicin was prepared in sterile water and diluted in MHB to obtain concentrations in a range of 16 to $0.016 \mu \mathrm{g} / \mathrm{mL}$. Additionally, susceptibility to gentamicin was confirmed using a quantitative assay for determining the MIC (gentamicin Test Strip Liofilchem ${ }^{\circledR}$ ) according to the manufacturers instructions. Microbial growth was determined by adding $10 \mu \mathrm{L}$ of $0.01 \%$ resazurin (7-hydroxy-3H-phenoxazin3 -one 10-oxide, HiMedia) aqueous solution. The MIC was defined as the lowest concentration of the samples inhibiting visible growth (blue colored pellet on the bottom of the wells after the addition of resazurin). To determine the MBC, the broth was taken from each well without visible growth and inoculated in Mueller-Hinton agar (MHA) for $24 \mathrm{~h}$ at $37^{\circ} \mathrm{C}$. The MBC was defined as the lowest sample concentration killing $99.9 \%$ of bacterial cells.

\subsection{Antioxidant activity}

Total potential antioxidant activity of tested essential oils was assessed based on their scavenging of 1,1-diphenyl-2picrylhydrazyl (DPPH-test) free radicals (Panda 2012). Reaction medium for DPPH-test was $3 \mathrm{~mL}$ aliquot of DPPH solution (24 mg DPPH in $100 \mathrm{~mL}$ methanol diluted to reach absorbance $0.980 \pm 0.02$ at $517 \mathrm{~nm}$ ) and $100 \mu \mathrm{L}$ of essential oil of varying dilutions in methanol. The solution in the test tubes was shaken and incubated in the dark for $30 \mathrm{~min}$ at room temperature. Calculations were done using ascorbic acid calibration curve and results were expressed as $\mu \mathrm{g}$ ascorbic acid equivalents $/ \mathrm{mL}$ essential oil required for scavenging $50 \%$ of tested radicals $\left(\mathrm{IC}_{50}\right)$. Lower values of $\mathrm{IC}_{50}$ indicate greater antioxidant activity.

\section{RESULTS AND DISCUSSION}

\subsection{Chemical characterization of essential oils}

Gas chromatographic and mass spectrometric analysis of the essential oil of winter savory (S. montana) showed 48 compounds, which represent $99.5 \%$ of the essential oil. The dominant compounds (higher than 5\%) in the essential oil were carvacrol with $43.2 \%$ and thymol with $28.4 \%$, followed by $p$-cymene $(8.9 \%)$ and $\gamma$-terpinene $(7.5 \%)$ (Table 1). Nevertheless, $\gamma$-terpinene and $p$-cymene are precursors of thymol and carvacrol and therefore some authors proposed that they are produced by a similar mechanism (Papadatou et al., 2015). Variety "Domaći" in general can be classified as phenol-rich chemotype since carvacrol and thymol are the most abundant compounds (Bezić et al., 2009).

Sage essential oil had 52 compounds, where the major compounds were cis-thujone with $27.1 \%$ and camphor with $19.3 \%$, followed by trans-thujone with $12.3 \%$, and 1,8-cineole with $11.5 \%$ (Table 2). Other abundant components presented in amount above $1 \%$ were: camphene $(4.6 \%)$, limonene $(4.4 \%)$, viridiflorol $(3.4 \%), \alpha$-pinene $(3.0 \%), \alpha$-humulene $(2.4 \%)$, manool $(1.9 \%)$, trans-caryophyllene $(1.7 \%)$ and $\beta$-pinene (1.6\%).

Qualitative analysis of the essential oil showed that S. officinalis variety "Primorska" belonged to Chemotype A, which is rich in cis-thujone and camphor (Cvetkovikj et al., 2015). However, the sum of toxic thujones, cis- and trans-thujone, was high (39.4\%) according to the Perry et al. (1999) who classified in 
Table 3. The essential oil composition of sage $S$. officinalis.

\begin{tabular}{|c|c|c|c|}
\hline \# & Compound name ${ }^{\mathrm{a}}$ & $\mathrm{RI}^{\mathrm{a}}$ & $\% \mathrm{~m} / \mathrm{m}$ \\
\hline 1 & n.i. & 881 & $\operatorname{tr}$ \\
\hline 2 & n.i. & 919 & $\operatorname{tr}$ \\
\hline 3 & $\alpha$-thujene & 925 & 0.3 \\
\hline 4 & $\alpha$-pinene & 932 & 0.7 \\
\hline 5 & camphene & 947 & 0.1 \\
\hline 6 & thuja-2,4(10)-diene & 952 & $\operatorname{tr}$ \\
\hline 7 & sabinene & 972 & 1.7 \\
\hline 8 & $\beta$-pinene & 975 & 12 \\
\hline 9 & myrcene & 990 & 1.5 \\
\hline 10 & $\alpha$-terpinene & 1016 & 0.1 \\
\hline 11 & p-cymene & 1023 & 0.1 \\
\hline 12 & $\beta$-phellandrene & 1028 & 4.1 \\
\hline 13 & 1,8-cineole & 1030 & 0.3 \\
\hline 14 & cis- $\beta$-ocimene & 1036 & $\operatorname{tr}$ \\
\hline 15 & trans- $\beta$-ocimene & 1046 & 0.1 \\
\hline 16 & $\gamma$-terpinene & 1057 & 0.2 \\
\hline 17 & cis-sabinene hydrate & 1066 & 0.1 \\
\hline 18 & linalool & 1100 & 0.4 \\
\hline 19 & cis-thujone & 1106 & 0.1 \\
\hline 20 & trans-thujone & 1116 & 0.1 \\
\hline 21 & nopinone & 1136 & 0.1 \\
\hline 22 & trans-pinocarveol & 1140 & 0.1 \\
\hline 23 & n.i. & 1157 & 1.8 \\
\hline 24 & trans-pinocamphone & 1158 & 20.5 \\
\hline 25 & pinocarvone & 1162 & 2.8 \\
\hline 26 & cis-pinocamphone & 1174 & 41.1 \\
\hline 27 & terpinen-4-ol & 1179 & 0.7 \\
\hline 28 & $\alpha$-terpineol & 1190 & 0.2 \\
\hline 29 & myrtenol & 1195 & 1.1 \\
\hline 30 & trans-2-hydroxy-pinocamphone & 1246 & 0.1 \\
\hline 31 & methyl myrtenate & 1296 & 0.1 \\
\hline 32 & myrtenyl acetate & 1324 & 0.1 \\
\hline 33 & n.i. & 1336 & $\operatorname{tr}$ \\
\hline 34 & $\alpha$-copaene & 1375 & $\operatorname{tr}$ \\
\hline 35 & $\beta$-bourbonene & 1384 & 0.6 \\
\hline 36 & $\alpha$-gurjunene & 1409 & 0.2 \\
\hline 37 & trans-caryophyllene & 1419 & 1.5 \\
\hline 38 & $\beta$-copaene & 1429 & $\operatorname{tr}$ \\
\hline 39 & n.i. & 1444 & $\operatorname{tr}$ \\
\hline 40 & $\alpha$-humulene & 1453 & 0.2 \\
\hline 41 & 9-epi-trans-caryophyllene & 1461 & 0.7 \\
\hline 42 & cis-muurola-4(14),5-diene & 1466 & $\operatorname{tr}$ \\
\hline 43 & germacrene D & 1482 & 1.7 \\
\hline 44 & n.i. & 1489 & $\operatorname{tr}$ \\
\hline 45 & bicyclogermacrene & 1497 & 1.3 \\
\hline 46 & $\gamma$-cadinene & 1515 & $\operatorname{tr}$ \\
\hline 47 & $\delta$-cadinene & 1523 & 0.2 \\
\hline 48 & elemol & 1550 & 1 \\
\hline 49 & n.i. & 1568 & $\operatorname{tr}$ \\
\hline 50 & spathulenol & 1577 & 0.4 \\
\hline 51 & caryophyllene oxide & 1583 & 0.2 \\
\hline 52 & veridiflorol & 1601 & 0.1 \\
\hline 53 & 10-epi- $\gamma$-eudesmol & 1619 & $\operatorname{tr}$ \\
\hline 54 & $\gamma$-eudesmol & 1632 & 0.2 \\
\hline 55 & $\tau$-cadinol & 1641 & 0.1 \\
\hline 56 & $\beta$-eudesmol & 1650 & 0.2 \\
\hline 57 & $\alpha$-eudesmol & 1654 & 0.2 \\
\hline 58 & n.i. & 1662 & $\operatorname{tr}$ \\
\hline 59 & n.i. & 1669 & $\operatorname{tr}$ \\
\hline & Monoterpene hydrocarbons & & 20.9 \\
\hline & Oxigenatedmonoterpenes & & 67.8 \\
\hline & Sesquiterpene hydrocarbons & & 6.4 \\
\hline & Oxigenatedsesquiterpenes & & 2.4 \\
\hline & Other & & 0.1 \\
\hline & Total identified & & 99.4 \\
\hline
\end{tabular}

${ }^{a}$ n.i. stands for not identified compounds; $\mathrm{tr}$ - traces.

${ }^{b}$ RI, retention indices as determined on HP- 5 column using homologous series of $C_{8}-C_{30}$ alkanes. this group all essential oils with $39-44 \%$ of thujone. However, a high concentration of toxic thujones seems to be characteristic to sage leaves cultivated in some countries under specific conditions (Maksimović et al., 2007; Raal et al., 2007).

The essential oil of hyssop (H. officinalis) had 59 compounds, where the most abundant compounds were cis- and transpinocamphone with $41.1 \%$ and $20.5 \%$, respectively, followed by $\beta$-pinene with $12.0 \%$ (Table 3 ). Other components presented in amounts above $1 \%$ were: $\beta$-phellandrene $(4.1 \%)$, pinocarvone $(2.8 \%)$, sabinene $(1.7 \%)$, germacrene D $(1.7 \%)$, myrcene $(1.5 \%)$, trans-caryophyllene $(1.5 \%)$, bicyclogermacrene $(1.3 \%)$, myrtenol $(1.1 \%)$ and elemol $(1.0 \%)$. Some authors found that the main components of the $\mathrm{H}$. officinalis essential oil (also from Serbia) were cis-pinocamphone $(42.9 \%)$, trans-pinocamphone $(14.1 \%)$, germacrene-D-11-ol (5.7\%) and elemol (5.6\%) (Mitić and Đorđević, 2000). However, the chemical composition of $H$. officinalis essential oil from Bulgaria had cis-pinocamphone $(48.98 \%-50.77 \%), \beta$-pinene $(13.38 \%-13.54 \%)$, trans-pinocamphone $(5.78 \%-5.94 \%)$ and $\beta$ phellandrene $(4.44 \%-5.17 \%)$ as the major compounds (Hristova et al., 2015).

\subsection{Antimicrobial properties}

The highest antimicrobial properties showed S. montana essential oil. The MIC was between 1.77 and $3.55 \mu \mathrm{L} / \mathrm{mL}$, while MBC was between 3.55 and $7.10 \mu \mathrm{L} / \mathrm{mL}$ (Table 4). S. montana essential oil was more effective than streptomycinin case of E. coli, E. faecalis, P. aeruginosa, S. epidermidis and $P$. hauseri, and more effective than gentamicin in case of $E$. coli and E. faecalis. However, other oils (S. officinalis and $H$. officinalis) showed lower efficiency than synthetic antibiotics and S. montana essential oil.

Obtained results show that $S$. montana essential oil contains mainly carvacrol (43.2\%) and thymol (28.4\%) (Table 1). Previous investigations confirmed that antimicrobial activity of essential oils was strongly correlated with the content of terpenoid phenols such as carvacrol and thymol (Benbelaiid et al., 2014), which can inhibit the growth of both Gram-positive and Gram-negative bacteria (Memar et al., 2017). Carvacrol and thymol have desired antimicrobial effect due to the change in permeability and depolarization of the cytoplasmic membranes of the bacteria (Xu et al., 2008).

Essential oil of S. montana from Macedonia showed high antimicrobial activity; MIC ranged from $12.5 \mu \mathrm{L} / \mathrm{mL}$ against S. epidermidis to $50 \mu \mathrm{L} / \mathrm{mL}$ against $P$. aeruginosa and $C$. albicans (Kundaković et al., 2014). However, S. montana essential oil from Croatia showed significant activity against fungi and Gram positive bacteria, especially Bacillus subtilis, $S$. epidermidis, and Listeria innocua, and among Gram negative bacteria extreme sensitivity was detected in E. coli (Marin et al., 2012). High antimicrobial potential classifies S. montana essential oil as a natural source of compounds that can be used in the treatment of foodborne, as well as wound and other infections, and for general health improvement, as well (Mihajilov-Krstev et al., 2014).

The results of antimicrobial activity of essential oil from the leaves of $S$. officinalis grown in Serbia confirmed the activity against $B$. subtilis, S. aureus, E. coli and S. enteritidis in two different concentrations; $1 \%$ and $2 \%$, in comparison to ampicillin (Miladinović and Miladinović, 2000). While, the essential oil of S. officinalis from Portugal showed very weak antimicrobial activity (Miguel et al., 2011). The same was concluded for $S$. officinalis essential oil from Greece that was lacking a noticeable antibacterial action since the MIC values recorded against all pathogens (Klebsiella oxytoca, K. pneumonia and E. coli) were above $150 \mu \mathrm{g} / \mathrm{mL}$ (Fournomiti et al., 2015).

H. officinalis has been traditionally used for its antiseptic prop- 
Table 4. Antimicrobial properties of essential oils, MIC and MBC $[\mu \mathrm{L} / \mathrm{mL}]$.

\begin{tabular}{|c|c|c|c|c|c|c|c|c|}
\hline & \multicolumn{2}{|c|}{ S. montana } & \multicolumn{2}{|c|}{ S. officinalis } & \multicolumn{2}{|c|}{ H. officinalis } & \multirow{2}{*}{$\begin{array}{r}\text { Streptomycin } \\
\text { MIC }\end{array}$} & \multirow{2}{*}{$\begin{array}{r}\text { Gentamicin } \\
\text { MIC }\end{array}$} \\
\hline & MIC & $\mathrm{MBC}$ & MIC & $\mathrm{MBC}$ & MIC & $\mathrm{MBC}$ & & \\
\hline Bacillus cereus & 1.77 & 3.55 & 113.62 & 227.25 & 14.20 & 28.40 & 1 & 0.19 \\
\hline \multicolumn{9}{|l|}{ (ATCC 11778) } \\
\hline Escherichia coli & 1.77 & 3.55 & 56.81 & 113.62 & 227.25 & 227.25 & 4 & 2 \\
\hline \multicolumn{9}{|l|}{ (ATCC 8739) } \\
\hline Enterococcus faecalis & 1.77 & 7.10 & 454.50 & 454.50 & 454.50 & 454.50 & 96 & 8 \\
\hline \multicolumn{9}{|l|}{ (ATCC 29212) } \\
\hline Pseudomonas aeruginosa & 3.55 & 3.55 & 113.62 & 227.25 & 454.50 & 454.50 & 16 & 1 \\
\hline \multicolumn{9}{|l|}{ (ATCC 27853) } \\
\hline Salmonella enteritidis & 3.55 & 7.10 & 113.62 & 113.62 & 227.25 & 227.25 & 2 & 0.5 \\
\hline \multicolumn{9}{|l|}{ (ATCC 13076) } \\
\hline Staphylococcus aureus & 3.55 & 3.55 & 113.62 & 113.62 & 227.25 & 227.25 & 3 & 0.38 \\
\hline \multicolumn{9}{|l|}{ (ATCC 25923) } \\
\hline Staphylococcus epidermidis & 3.55 & 3.55 & 113.62 & 113.62 & 227.25 & 227.25 & $>1024.00$ & 0.094 \\
\hline \multicolumn{9}{|l|}{ (ATCC 12228) } \\
\hline Proteus hauseri & 3.55 & 3.55 & 454.50 & 454.50 & 227.25 & 454.50 & 6 & 1 \\
\hline (ATCC 13315) & & & & & & & & \\
\hline
\end{tabular}

erties in the treatment of infectious disorders (Mahboubi et al., 2011). Some previous studies showed the significant activity of $H$. officinalis essential oil against Gram-positive bacteria (Baj et al., 2018; De Martino et al., 2009; Mahboubi et al., 2011). Other reported that $H$. officinalis essential oil MIC ranged from 15.625 to $250 \mu \mathrm{L} / \mathrm{mL}$ depending on bacterial strains (Özer et al., 2006).

\subsection{Antioxidative activity}

S. montana showed the highest antioxidant capacity when compared to other tested species (Table 5). H. officinalis and S. officinalis followed with 1.5 and 3-fold lower antioxidant activity, respectively. All available literature mostly performed DPPH-test on extracts of analyzed plants and only a few of them used essential oils, as it was the case in our research.

Table 5. Antioxidative activity of cultivated savory, sage and hyssop essential oils.

\begin{tabular}{lc}
\hline Species & $\mathrm{IC}_{50}[\mu \mathrm{g} / \mathrm{mL}]$ \\
\hline Satureja montana & $17.0 \pm 0.1$ \\
Salvia officinalis & $50.0 \pm 0.4$ \\
Hyssopus officinalis & $24.0 \pm 0.2$ \\
\hline
\end{tabular}

If compared with literature data, S. montana essential oil tested in this study has greater antioxidant capacity than other S. montana plants collected in nature (Ćavar et al., 2008; Coutinho de Oliveira et al., 2012), or compared with other Satureja species: $32 \mu \mathrm{g} / \mathrm{mL}$ in S. cilicica (Ozkan et al., 2007)nd $185.5 \mu \mathrm{g} / \mathrm{mg}$ in S. cuneifolia (Oke et al., 2007). DPPH-test of $S$. officinalis essential oil showed lower antioxidant capacity than those from published data which reported $\mathrm{IC}_{50}$ activity as 1.78 $\mu \mathrm{g} / \mathrm{L}$ (Bozin et al., 2007). Results from other studies varied for H. officinalis: $16.37 \mu \mathrm{g} / \mathrm{mL}$ (Kizil et al., 2010) and $156.6 \mathrm{mg} / \mathrm{mL}$ (Džamić et al., 2013).

\section{CONCLUSION}

With on-going use of an artificial preservative in the food industry, in addition to the challenge of microbial resistance, there is growing concern over side effects of these compounds. Alternatives such as the use of herbal essential oils in food preservation that have no side effects and sometimes even positive effects have to be considered. According to the presented results, $S$. montana essential oils could be proposed as an invaluable source of natural preservatives. Despite cultivation practice, our results showed that essential oils obtained from commercially grown varieties have high biological activity and could be used instead of plants grown in nature. In this way, more raw materials could be produced without effect on natural gene pool and habitats of these species.

\section{ACKNOWLEDGMENTS}

Financial support by the Serbian Ministry of Education and Science (Project No. TR 31025) for this work is gratefully acknowledged.

\section{REFERENCES}

Baj, T., Korona-Głowniak, I., Kowalski, R. and Malm, A. (2018). Chemical composition and microbiological evaluation of essential oil from Hyssopus officinalis L. with white and pink flowers, Open Chemistry 16(1): 317-323. 
Benbelaïd, F., Khadir, A., Abdoune, M. A., Bendahou, M., Muselli, A. and Costa, J. (2014). Antimicrobial activity of some essential oils against oral multidrug-resistant Enterococcus faecalis in both planktonic and biofilm state, Asian Pacific Journal of Tropical Biomedicine 4(6): 463-472.

Bezić, N., Šamanić, I., Dunkić, V., Besendorfer, V. and Puizina, J. (2009). Essential oil composition and internal transcribed spacer (ITS) sequence variability of four south-croatian Satureja species (Lamiaceae), Molecules 14(3): 925-938.

Bozin, B., Mimica-Dukic, N., Samojlik, I. and Jovin, E. (2007). Antimicrobial and antioxidant properties of rosemary and sage (Rosmarinus officinalis L. and Salvia officinalis L., Lamiaceae) essential oils, Journal of Agricultural and Food Chemistry 55(19): 7879-7885.

Carović-Stanko, K., Petek, M., Grdiša, M., Pintar, J., Bedeković, D., Herak Ćustić, M. and Satovic, Z. (2016). Medicinal plants of the family Lamiaceae as functional foods - a review, Czech Journal of Food Sciences 34(5): 377-390.

Ćavar, S., Maksimović, M., Šolić, M. E., Jerković-Mujkić, A. and Bešta, R. (2008). Chemical composition and antioxidant and antimicrobial activity of two Satureja essential oils, Food Chemistry 111(3): 648-653.

CLSI (2012). M07-A9: Methods for dilution antimicrobial susceptibility tests for bacteria that grow aerobically; approved standard-ninth edition, Wayne, PA: Clinical and laboratory standards Institute.

Coutinho de Oliveira, T. L., Malfitano de Carvalho, S., de Araújo Soares, R., Andrade, M. A., Cardoso, M. d. G., Ramos, E. M. and Piccoli, R. H. (2012). Antioxidant effects of Satureja montana L. essential oil on TBARS and color of mortadella-type sausages formulated with different levels of sodium nitrite, LWT - Food Science and Technology 45(2): 204-212.

Cvetkovikj, I., Stefkov, G., Karapandzova, M., Kulevanova, S. and Satović, Z. (2015). Essential oils and chemical diversity of southeast european populations of Salvia officinalis L ., Chemistry \& Biodiversity 12(7): 1025-1039.

Džamić, A. M., Soković, M. D., Novaković, M., Jadranin, M., Ristić, M. S., Tešević, V. and Marin, P. D. (2013). Composition, antifungal and antioxidant properties of Hyssopus officinalis L. subsp. pilifer (Pant.) Murb. essential oil and deodorized extracts, Industrial Crops and Products 51: 401-407.

De Martino, L., De Feo, V. and Nazzaro, F. (2009). Chemical composition and in vitro antimicrobial and mutagenic activities of seven Lamiaceae essential oils, Molecules 14(10): 42134230.

Dehghanzadeh, N., Ketabchi, S. and Alizadeh, A. (2012). Essential oil composition and antibacterial activity of Hyssopus officinalis L. grown in Iran., Asian Journal of Experimental Biological Sciences 3(4): 767-771.

Fathiazad, F., Mazandarani, M. and Hamedeyazdan, S. (2011). Phytochemical analysis and antioxidant activity of Hyssopus officinalis L. from Iran, Advanced Pharmaceutical Bulletin 1(2): 63-67.

Fournomiti, M., Kimbaris, A., Mantzourani, I., Plessas, S., Theodoridou, I., Papaemmanouil, V., Kapsiotis, I., Panopoulou, M., Stavropoulou, E., Bezirtzoglou, E. E. and Alexopoulos, A. (2015). Antimicrobial activity of essential oils of cultivated oregano (Origanum vulgare), sage (Salvia officinalis ), and thyme (Thymus vulgaris ) against clinical isolates of Escherichia coli, Klebsiella oxytoca, and Klebsiella pneumoniae, Microbial Ecology in Health $\mathcal{E}$ Disease 26(0).

Ghorbani, A. and Esmaeilizadeh, M. (2017). Pharmacological properties of Salvia officinalis and its components, Journal of Traditional and Complementary Medicine 7(4): 433-440.

Hristova, Y., Wanner, J., Jirovetz, L., Stappen, I., Iliev, I. and Gochev, V. (2015). Chemical composition and antifungal activity of essential oil of Hyssopus officinalis L. from Bulgaria against clinical isolates of Candida species, Biotechnology $\mathcal{E}$ Biotechnological Equipment 29(3): 592-601.

Kizil, S., Hasimi, N., Tolan, V., Kilinc, E. and Karatas, H. (2010). Chemical composition, antimicrobial and antioxidant activities of hyssop (Hyssopus officinalis L.) essential oil, Notulae Botanicae Horti Agrobotanici Cluj-Napoca 38(3): 99-103.

Kundaković, T., Stanojković, T., Kolundžija, B., Marković, S., Šukilović, B., Milenković, M. and Lakušić, B. (2014). Cytotoxicity and Antimicrobial Activity of the Essential Oil from Satureja montana subsp. pisidica (Lamiceae), Natural Product Communications 9(4): 1934578X1400900.

Mahboubi, M., Haghi, G. and Kazempour, N. (2011). Antimicrobial Activity and Chemical Composition of Hyssopus officinalis L. Essential oil, Journal of Biologically Active Products from Nature 1(2): 132-137.

Maksimović, M., Vidic, D., Miloš, M., Edita Šolić, M., Abadžić, S. and Siljak-Yakovlev, S. (2007). Effect of the environmental conditions on essential oil profile in two Dinaric Salvia species: S. brachyodon Vandas and S. officinalis L., Biochemical Systematics and Ecology 35(8): 473-478.

Mapes, C. and Xu, Y. (2014). Photosynthesis, vegetative habit and culinary properties of sage (Salvia officinalis) in response to low-light conditions, Canadian Journal of Plant Science 94(5): 881-889.

Marin, M., Novaković, M., Tešević, V., Vučković, I., Milojević, N., Vuković-Gačić, B. and Marin, P. D. (2012). Antioxidative, antibacterial and antifungal activity of the essential oil of wild-growing Satureja montana L. from Dalmatia, Croatia: Essential oil activity of Satureja montana L., Flavour and Fragrance Journal 27(3): 216-223.

Memar, M. Y., Raei, P., Alizadeh, N., Akbari Aghdam, M. and Kafil, H. S. (2017). Carvacrol and thymol: strong antimicrobial agents against resistant isolates, Reviews in Medical Microbiology 28(2): 63-68.

Miguel, G., Cruz, C., Faleiro, M., Simões, M., Figueiredo, A., Barroso, J. and Pedro, L. (2011). Salvia officinalis L. essential oils: effect of hydrodistillation time on the chemical composition, antioxidant and antimicrobial activities, Natural Product Research 25(5): 526-541.

Mihajilov-Krstev, T., Radnović, D., Kitić, D., Jovanović, V., Mitić, V., Stojanović-Radić, Z. and Zlatković, B. (2014). Chemical composition, antimicrobial, antioxidative and anticholinesterase activity of Satureja montana L. ssp. montana essential oil, Open Life Sciences 9(7).

Miladinović, D. and Miladinović, L. (2000). Antimicrobial activity of essential oil of sage from Serbia, Facta Universitatis, Series: Physics, Chemistry and Technology 2(2): 97-100.

Mitić, V. and Đorđević, S. (2000). Essential oil composition of Hyssopus officinalis l. cultivated in Serbia, Facta Universitatis, Series: Physics, Chemistry and Technology 2(2): 105-108. 
Özer, H., Sökmen, M., Güllüce, M., Adigüzel, A.and Kiliç, H., Şahin, F., Sökmen, A. and Bariş, . (2006). In vitro antimicrobial and antioxidant activities of the essential oils and methanol extracts of Hyssopus officinalis L. ssp. angustifolius, Italian Journal of Food Science 18(1): 73-83.

Ozkan, G., Simsek, B. and Kuleasan, H. (2007). Antioxidant activities of Satureja cilicica essential oil in butter and in vitro, Journal of Food Engineering 79(4): 1391-1396.

Papadatou, M., Argyropoulou, C., Grigoriadou, C. and Maloupa, E. (2015). Essential oil content of cultivated Satureja spp. in Northern Greece, NVEO - Natural Volatiles E Essential Oils 2(1): 37-48.

Perry, N. B., Anderson, R. E., Brennan, N. J., Douglas, M. H., Heaney, A. J., McGimpsey, J. A. and Smallfield, B. M. (1999). Essential oils from dalmatian sage (Salvia officinalis L.): variations among Individuals, plant parts, seasons, and sites, Journal of Agricultural and Food Chemistry 47(5): 2048-2054.

Ph. Eur. 7.0. (2010). European Pharmacopoeia 7.0., Council of Europe, Strasbourg.

Raal, A., Orav, A. and Arak, E. (2007). Composition of the essential oil of Salvia officinalis L. from various European countries, Natural Product Research 21(5): 406-411.

Tepe, B. and Cilkiz, M. (2016). A pharmacological and phytochemical overview on Satureja, Pharmaceutical Biology 54(3): 375-412.

Venkateshappa, S. M. and Sreenath, K. P. (2013). Potential medicinal plants of Lamiaceae, American International Journal of Research in Formal, Applied E Natural Sciences 13(239): 82-87.

Wesołowska, A., Grzeszczuk, M. and Jadczak, D. (2014). Influence of harvest term on the content of carvacrol, $p$-cymene, $\gamma$-terpinene and $\beta$-caryophyllene in the essential oil of $\mathrm{Sa}$ tureja montana, Notulae Botanicae Horti Agrobotanici ClujNapoca 42(2): 392-397.

Xu, J., Zhou, F., Ji, B.-P., Pei, R.-S. and Xu, N. (2008). The antibacterial mechanism of carvacrol and thymol against Escherichia coli, Letters in Applied Microbiology 47(3): 174-179. 